\title{
The Contribution of Fish to Food and Nutrition Security in Eastern Africa: Emerging Trends and Future Outlooks
}

\author{
Kevin Obiero ${ }^{1,2, *(1)}$, Paul Meulenbroek ${ }^{2, *}$, Silke Drexler ${ }^{2}$, Adamneh Dagne ${ }^{3}$, Peter Akoll ${ }^{4}$, \\ Robinson Odong ${ }^{4} \mathbb{D}$, Boaz Kaunda-Arara ${ }^{5}$ and Herwig Waidbacher ${ }^{2}$ \\ 1 Kenya Marine and Fisheries Research Institute (KMFRI), Pap-Onditi 136-40111, Kenya \\ 2 Department of Water, Atmosphere and Environment, University of Natural Resources and Life Sciences, \\ Gregor-Mendel-Straße 33, A-1180 Vienna, Austria; silke.drexler@boku.ac.at (S.D.); \\ herwig.waidbacher@boku.ac.at (H.W.) \\ 3 National Fisheries and Aquatic Life Research Center, Sebeta 64, Ethiopia; adamnehdet@gmail.com \\ 4 Department of Zoology, Entomology and Fisheries Sciences, School of Biosciences, \\ College of Natural Sciences, Makerere University, Kampala 7062, Uganda; akollp@gmail.com (P.A.); \\ rabin.odong@gmail.com (R.O.) \\ 5 Department of Fisheries and Aquatic Sciences, University of Eldoret, Eldoret 1125-30100, Kenya; \\ b_kaunda@yahoo.com \\ * Correspondence: kevobiero@gmail.com (K.O.); paul.meulenbroek@boku.ac.at (P.M.)
}

Received: 12 February 2019; Accepted: 14 March 2019; Published: 18 March 2019

\begin{abstract}
Approximately 200 million people in Africa derive high-quality and low-cost proteins from fish. However, the consumption of fish is not fully exploited to combat the "triple burden" of malnutrition—obesity, undernutrition, and micronutrient deficiencies which are the leading causes of poor health in the region. There is still limited knowledge on quantitative information to guide policy makers in developing evidence-based actions that can improve the availability of and access to nutritious food for healthy and sustained diets among children and care givers. In this paper, we review the available literature with the aim of assessing and quantifying the extent to which fish contributes towards fighting food and nutrition insecurity in the Eastern Africa subregion. Key results reveal the region is characterized by fish supply deficits, and hence, low levels of fish consumed per person. Nonetheless, the increase in fish imports, and the growing supply of fish from aquaculture are likely to improve the per-capita fish intake. Fish trade is generally bidirectional, with exports exceeding imports in value terms, while significant challenges still hinder domestic and intra-regional fish trade. The Eastern Africa region is projected to realize increased fish consumption from $4.80 \mathrm{~kg}$ in 2013 to $5.49 \mathrm{~kg}$ by 2022. Rising population growth and income levels imply that the region will need 2.49 million tonnes of fish to fill the demand-supply gaps. We recommend that food security and nutritional programmes should recognize the potential of fish in providing essential micronutrients from the aspects of improved dietary quality, nutritional status, and general wellbeing of the region's fast growing population.
\end{abstract}

Keywords: fish; food security; aquaculture; production; consumption; trade and marketing; Eastern Africa

\section{Introduction}

The United Nation's 2030 development agenda adopted in 2015 [1] outlines 17 Sustainable Development Goals (SDGs) with a corresponding 169 targets that are expected to guide national, regional, and international agencies' actions to achieve sustainable development over the next 
decade [1]. In particular, SDG 2 aims at addressing all forms of hunger, as well as food and nutritional insecurity. Despite significant progress being made towards reducing hunger and combating malnutrition and food insecurity, significant challenges persist. The State of Food Security and Nutrition in the World (2018) revealed that over the past three years, the human population suffering from hunger has increased to levels recorded a decade ago [2]. Almost 1 billion people are food- and nutrient-insecure, posing a greater risk to diet-related non-communicable diseases [2,3]. The emerging "triple burden" of malnutrition-obesity, undernutrition, and micronutrient deficiencies-are now the leading cause of poor health globally $[4,5]$. Recent studies advocate for changes in global food production systems, for the provision of high-quality dietary requirements, to achieve the SDG 2 and the Paris Agreement targets [5,6].

Fish, including finfish and shellfish, contribute $17 \%$ of animal protein, and $7 \%$ of all proteins, and are crucial for over 3 billion people in developing countries [7]. Fish provides high-quality essential amino acids, docosahexaenoic and eicosapentaenoic omega-3 fatty acids, minerals, especially iron, zinc, and vitamins, often in highly bioavailable forms [6,8]. As such, fish is widely recognized as "nature's superfood" [9]. Globally, fish consumption rates is growing faster than the global population growth, because of increased incomes and awareness of the health benefits associated with consuming fish, as well as rising urbanization [10]. In addition to directly providing high-quality food, fisheries and aquacultures create economic value through the production, trade, and marketing of wild and farmed fish [11].

Fish food is obtained from marine and freshwater-capture fisheries and aquaculture. Taken together, these fish production systems have contributed to the impressive growth of fish production within six decades, rising from 19 million metric tonnes (MT) in 1950 to 171 million MT in 2016 [7]. Global capture fisheries production peaked in 1996 at around 96 million MT. In contrast, aquaculture production has doubled every decade for the past 50 years to produce 80 million MT of food fish, 30.1 million MT of aquatic plants and 38,000 MT of non-food products in 2016 [7,12]. In 2014, aquaculture overtook capture fisheries in the provision of fish for human consumption [6,13]. As the global fastest growing food production sector, the future expansion of fish as food is expected to come from aquaculture in the next decades. According to the OECD-FAO Agriculture Outlook global fish production will increase by more than $1 \%$ p.a. over the next decade to $195 \mathrm{MT}$ by 2027, owing to an increase in aquaculture production [14]. Indeed, the outlook projects a $30.1 \%$ growth in aquaculture production, equivalent to 24 MT between 2018 and 2027, which will result in aquaculture surpassing capture fisheries production in 2020 [14]. However, food fish availability can also be increased through reductions in post-harvest losses and waste.

The fisheries and aquaculture sectors in Africa are increasingly contributing to food and nutrition security, foreign exchange, employment, and livelihood support services [15]. The New Partnership for Africa's Development (NEPAD) estimates that total fishery production in the region stands at 10.4 million tonnes [16] comprising of 6.0 million tonnes from marine capture fisheries, 2.8 million tonnes from inland water fisheries, and about 1.6 million tonnes from aquaculture. Currently, more than $30 \%$ of the continent's population, or roughly 200 million people, consume fish as the main animal protein source and micronutrition [16]. Besides, 12.3 million people in Africa work in the fisheries and aquaculture sector, with 6.1 million ( $50 \%$ ) being employed as fishers, 5.3 million (42\%) as processors and 0.9 million ( $8 \%)$ as fish farmers [15]. In terms of economic value, fish produces an estimated total of US\$24 billion annually, accounting for $1.26 \%$ of gross domestic product (GDP) [16].

However, the continent continues to be burdened with numerous problems that are impeding long-term resource sustainability, reducing prospects for increasing its contribution to food security, poverty alleviation, and wealth creation [16]. Sub-Saharan Africa had the highest proportion of undernourished people globally, accounting for 25\% (224 million people) in 2016 [17]. Aquaculture in Africa is still in its infancy and is practised in only a few countries fetching an estimated US\$3 billion annually [15]. Although the aquaculture industry in the continent is growing faster than any other part of the world, Africa contributes least to the amount of fish produced, consumed, and traded 
globally [18-20]. For instance, aquaculture contributed $17 \%$ of total fish production in Africa, which is equivalent to a paltry $2.5 \%$ of global fish production in 2016 [7]. Taken against the backdrop of wider regional food insecurity and a projection that Africa's population will double by 2050 [21], aquaculture is poised to play an important role in providing valuable animal protein foods to poor and food-insecure populations [22-24]. Considering that 33\% of the wild fish stocks are overexploited [7], aquaculture will play a critical role in meeting increased fish demand in Africa [25].

Since aquaculture in Sub-Saharan Africa is young and growing, the sector is experiencing complex socio-economic and environmental impacts that require systematic quantitative assessment and monitoring approaches toward achieving evidence-based policy planning. However, there are still gaps in quantitative information to guide decision-makers in formulating national and regional policies to optimize synergies between the socio-economic development and environmental performance of the sector. The Fisheries and Aquaculture Department of the Food and Agriculture Organization (FAO) acknowledges that quantitative information on aquaculture's socioeconomic and environmental performance is scattered in the literature, "leading to underutilization and sometimes misuse of available information". In this paper, we present current knowledge to guide national and regional policy formulation and implementation in Eastern Africa (EA) subregion. Given the recognition of fish as "nature's superfood", crucial in alleviating malnutrition in all its forms, we reviewed published information to inform the policies that recognize tradeoffs and synergies that are aimed at tackling food insecurity and malnutrition in the region. The paper synthesizes current information on the extent to which fish contributes to food and nutrition security by highlighting recent production trends, consumption, and trade in the EA subregion.

\section{Methods}

In this study, we used a combination of tools and models to assess the performance of the fisheries and aquaculture sector, to provide national, regional and global projections on fish supply and demand. First, we used two user-friendly data tools: (i) the World Aquaculture Performance Indicators (WAPI) Production Module [26], and (ii) the WAPI Fish Consumption Module [27], to assess and monitor aquaculture sector performance. The tools compile, package, and disseminate data and information collected from various sources to assist in evidence-based policymaking in fisheries and aquaculture. The WAPI Production module analyses the volumes and values of over 650 freshwater and marine species in nearly 250 countries over the past seven decades, from 1950 to 2016 [26]. On the other hand, the WAPI Fish Consumption Module examines food supply and utilization patterns and monitors three nutrition and seven food indicators in 270 countries over a specified timeframe [27]. Second, data on the production, consumption, and trade projections for fish and seafood from 2018 to 2027 were obtained from the OECD-FAO Agricultural Outlook report [14]. Third, we used data from the short-term projection model developed by FAO's Fisheries and Aquaculture Department, to assess and monitor potential future national, regional, and global fish supply and demand, as well as to estimate aquaculture stopgap requirements, to fulfill supply [28]. This short-term model estimates: (i) growth in fish demand, due to income and population growth; (ii) growth in the supply trends from aquaculture; and (iii) other indicators that measure demand-supply gaps [28]. Finally, we reviewed long-term fish projections in the updated version of the International Model for Policy Analysis of Agriculture Commodities and Trade (IMPACT), developed by the International Food Policy Research Institute (IFPRI), in collaboration with WorldFish, FAO's Fisheries and Aquaculture Department, and the University of Arkansas at Pine Bluff $[29,30]$. Apart from these models and tools, we also scoped for information in published research in peer-reviewed articles, books, book chapters, thesis/dissertations, and conference proceedings. 


\section{Results}

\subsection{Fish Production}

Historically, Africa's fisheries output is dominated by capture fisheries, but the contribution of aquaculture to the total amount of fish produced in the region has grown at a steady pace over the past decade [19]. In the Eastern Africa region countries comprising Burundi, Ethiopia, Kenya, Rwanda, Uganda, and Tanzania, fish is produced from freshwater inland and marine capture fisheries and aquaculture [31]. These three sources of fish play complementary roles in: (a) supporting rising fish demand, and (b) improving incomes and food and nutrition security of smallholder producers, fishers and consumers in rural and urban areas. The inland capture fishery sectors provide most of the sub-regions' fishery production (Table 1). However, fish catches from wild sources have been declining, due to multiple anthropogenic pressures including climate change, overfishing, habitat destruction, invasion of non-native species, illegal, unreported, and unregulated fishing (IUU), and poor governance [32-34].

Taken together, aquaculture production in the EA subregion is relatively small, compared to the top producers in Africa-Egypt (c. 1.37 million tonnes) and Nigeria (c. 306,727 tonnes) [26] (Table 1). Aquaculture production is dominated by tilapia farming, which is also the most popular fish from a consumer perspective [35,36]. Uganda has the highest aquaculture production of 118,000 tonnes harvested from 25,000 ponds covering 10,000 hectares in 2016 [37]. Kenya is also a regional player in the growth of aquaculture, as the fourth largest producer of farmed fish in Africa, having experienced a significant growth from 4452 tonnes in 2008 to a peak at 24,096 tonnes in 2014, spurred by a large-scale aquaculture subsidy programme under the Economic Stimulus Programme (ESP) from 2009-2013 [38]. In Burundi, Ethiopia and Tanzania, aquaculture contributes $<10 \%$ to the total fish production; thus, more attention is needed to prioritize the development of the sector in these countries, taking advantage of the diverse aquatic resources that support fish production. Generally, the increase in aquaculture production in the region has been attributed to increased levels of investment by the private sector, and deliberate public-sector interventions [31,36]. It is anticipated that increase in fish supplies from aquaculture will contribute to achieving hunger-free and food, and nutrition secure nations.

Table 1. Capture and aquaculture production of fish in the EA subregion in 2016.

\begin{tabular}{ccccc}
\hline Country & $\begin{array}{c}\text { Capture Fisheries } \\
\text { Production } \\
\text { (Tonnes) }\end{array}$ & $\begin{array}{c}\text { Aquaculture } \\
\text { Production } \\
\text { (Tonnes) }\end{array}$ & $\begin{array}{c}\text { Total Domestic } \\
\text { Fish Supply } \\
\text { (Tonnes) }\end{array}$ & $\begin{array}{c}\text { Aquaculture as a } \\
\text { Share of Fish } \\
\text { Production (\%) }\end{array}$ \\
\hline Sub-Saharan Africa & $7,254,848$ & 592,540 & $7,847,388$ & 7.8 \\
Egypt & 335,613 & $1,370,660$ & $1,706,273$ & 81.73 \\
Nigeria & 734,731 & 306,727 & $1,041,458$ & 30.62 \\
Burundi & 20,120 & 1,326 & 21,446 & 6.2 \\
Ethiopia & 45,519 & 91 & 45,610 & 0.2 \\
Kenya & 165,135 & 18,658 & 183,793 & 11.3 \\
Rwanda & 29,334 & 4,847 & 34,181 & 14.2 \\
Tanzania & 371,228 & 10,742 & 381,970 & 2.8 \\
Uganda & 396,205 & 117,590 & 513,795 & 22.9 \\
\hline
\end{tabular}

Data Source: WAPI-AQPRN v.2018.1 [26]

\subsection{The Food Security Situation in Eastern Africa}

The economic performance indicators vary significantly across the EA subregion. Ethiopia and Kenya are the dominant economies in the region, with an average GDP growth of $6.2 \%$ in 2018 , being projected to grow to $6.4 \%$ in 2019 and $6.5 \%$ in 2020, due to large infrastructure investments and growing domestic markets [39]. Agriculture is East Africa's most important sector, supporting livelihoods of over $80 \%$ of the region's population. Despite this crucial role, almost all countries (except Ethiopia) 
have not achieved at least $10 \%$ of the budget allocation towards agriculture and rural development, according to the Maputo Declaration [40]. Due to the low capital investments in the agricultural sector, millions of people continued to suffer from malnutrition in all its forms, with significant social and economic impacts [41].

With a total population close to 300 million-almost a quarter of Africa's population-East Africa was the second sub-region after Southern Asia, having the highest food insecure population in 2016 [2,40]. Recent reports have revealed that between 2015 and 2017, about 72.9 million people were undernourished, 2.7 million children below five years old were affected by wasting, 14.7 million children below five years old were stunted, and 1.5 million children under five years old were overweight in the region [2]. Indeed, Table 2 reveals that the prevalence of malnutrition was higher among children under five years of age than the World Health Organization (WHO) recommended thresholds [42]. Although Burundi has the highest prevalence (55\%) of children under five years old who are stunted in the world; Ethiopia, Kenya, Tanzania, and Uganda-fall within the top 20 countries, having a high number of undernourished people [41]. The high malnutrition incidences in the region correspond to a low quantity of fish consumed/capita, which was estimated at $5.3 \mathrm{~kg}$ in 2013 (Table 4) and the lower average per capita caloric intake (2205 kcal/capita/day), compared to the global average intake of 2,900 kcal/capita/day (Table 2). Yet, fish is widely recognized as a rich source of essential fatty acids, especially docosahexaenoic acid (DHA), minerals, vitamins, and essential amino acids [6,43], which are required for improved health, especially in supporting physical and mental development and functioning [43]. The consequences of malnutrition are severe economically, considering that over $20 \%$ of the population are unable to acquire sufficient and quality food to meet their dietary requirements.

Table 2. Population, economic indicators, and hunger dimensions for Eastern Africa counties.

\begin{tabular}{|c|c|c|c|c|c|c|c|}
\hline Economic & Burundi & Ethiopia & Kenya & Rwanda & Tanzania & Uganda & World \\
\hline Population (in millions) 2016 & 10.9 & 105.0 & 49.7 & 12.2 & 57.3 & 42.9 & $7,550.3$ \\
\hline $\begin{array}{l}\text { Gross Domestic Product } \\
\text { (Current UD\$, billions) }\end{array}$ & 3172 & 80,562 & 79,263 & 9135 & 52,090 & 25,995 & \\
\hline Rural population, total (millions) & 10.0 & 82.7 & 36.1 & 9.1 & 37.1 & 35.6 & $3,373.5$ \\
\hline $\begin{array}{l}\text { Government expenditure on agriculture \& } \\
\text { fishing ( } \% \text { total outlays) }\end{array}$ & 2.8 & 15.9 & 1.5 & 3.0 & 1.1 & 4.0 & - \\
\hline $\begin{array}{l}\text { Employment in agriculture sector } \\
\text { (including fisheries and aquaculture) \% }\end{array}$ & 96.4 & 69.0 & 38.1 & 66.9 & 67.2 & 70.4 & 26.7 \\
\hline \multicolumn{8}{|c|}{ Hunger and malnutrition dimensions } \\
\hline $\begin{array}{c}\text { Average dietary energy supply } \\
\text { (kcal/cap/day) }\end{array}$ & - & 2330 & 2217 & 2203 & 2241 & 2033 & 2904 \\
\hline Prevalence of undernourishment $(\%)$ & - & 21.4 & 24.2 & 36.1 & 32.0 & 41.4 & 10.9 \\
\hline Stunting in children under $5(\%)$ & 55.9 & 38.4 & 26.0 & 37.9 & 34.4 & 28.9 & 22.7 \\
\hline Wasting in children under $5(\%)$ & 5.1 & 9.9 & 4.0 & 2.2 & 4.5 & 3.6 & 7.5 \\
\hline $\begin{array}{c}\text { Number of undernourished people } \\
\text { (million) }\end{array}$ & n.a & 21.9 & 11.7 & 4.3 & 17.8 & 17.2 & 803.1 \\
\hline $\begin{array}{c}\text { Number of wasted children }<5 \text { years } \\
\text { (million) }\end{array}$ & 0.1 & 1.5 & 0.3 & $<0.1$ & 0.4 & 0.3 & 50.5 \\
\hline $\begin{array}{l}\text { Number of stunted children }<5 \text { years } \\
\text { (million) }\end{array}$ & 1.1 & 5.8 & 1.8 & 0.6 & 3.2 & 2.2 & 150.8 \\
\hline $\begin{array}{c}\text { Number of overweight children }<5 \\
\text { (million) }\end{array}$ & $<0.1$ & 0.4 & 0.3 & 0.1 & 0.3 & 0.3 & 38.5 \\
\hline
\end{tabular}

Data Source: FAO Statistical Pocketbook [41], WAPI- FISHCSP v.2018.1 [27] and UN-DESA [21].

Recently, [44] proposed a reference flexitarian diet to include $28 \mathrm{~g}$ of fish/day to provide essential omega 3 fatty acids that are critical in reducing the risks of heart disease. More importantly, increasing the consumption of fish, especially nutrient-rich small fish, among pregnant and lactating women and small children can make a real difference in the nutritional wellbeing of poor communities [45-47]. In Kenya, for instance, a study on the contribution of fish farming to the reduction of undernutrition in children ( $<5$ years) within households and communities in the Central Province of Kenya revealed that the "weight for age" and "height for age" were significantly higher in children from fish farming 
households than those who live on farms without any access to fish farming [48]. This suggests that children living among fish farming families are more nutritionally favored. The study is consistent with results from Malawi, which reported lower prevalence of stunting and underweight children living among fish-farming than non-fish-farming households [49].

\subsection{Contribution of Fish to Food and Nutrition Security}

Several publications recognize the full potential of fish in improving the food and nutritional security of the rural poor, especially of women and young children $[45,47,50,51]$. In per capita terms, global fish consumption increased at an average of about 1.5\% per year from $9.0 \mathrm{~kg}$ in 1961 to $20.2 \mathrm{~kg}$ in 2015 [7]. The amount of fish consumed globally is projected to increase to an average of $21.3 \mathrm{~kg}$ in 2027 from $20.5 \mathrm{~kg}$, in the 2015 to 2017 period [14]. Africa's fast-growing human population outstrips growth in fish supply, and most of the continent's wild fish populations are fully exploited. Therefore, aquaculture production must more than double by 2050 to satisfy the projected fish demand [28]. Despite fish providing 19\% of animal protein intake in Africa, the annual per capita fish consumption remains lower than the global levels [25]. The key driving forces behind increased fish consumption are rapid population growth, rising incomes, urbanization, a growing appreciation of healthy and nutritious fish-based food, and innovations in processing and packaging technologies and distribution channels $[10,14]$.

Eastern African region exhibits remarkably low levels of fish consumption per capita (average of $5.3 \mathrm{kgs}$ ) compared to the rest of Africa $(10.1 \mathrm{~kg}$ ), and global level of $19.8 \mathrm{~kg}$ (Table 3$)$. On a positive note, it is the only subregion that has had an increase in per capita consumption, and in the share in world fish consumption, from $1.08 \%$ to $1.26 \%$ between 2008 and 2013 [28]. In per capita terms, only Uganda's per capita fish consumption of $12.5 \mathrm{~kg}$ was higher than the rest of Sub-Saharan Africa. Although there was a significant proportion of protein intake among households in the EA subregion from animal sources; the per capita intake was far less than the world's average of $32 \mathrm{~g} / \mathrm{capita} /$ day [27]. More importantly, the percentage share of fish in animal protein intake in Burundi, Rwanda, Tanzania, and Uganda was more than the world average, signifying the crucial role that fish plays in food and nutrition security, in a region characterized by a low consumption of animal proteins. The main reasons driving fish preferences and consumption are low prices (average of US $\$ 2 / \mathrm{kg}$ ), an awareness of fish as a healthy food source, changing consumer tastes and preferences, the mode of processing, the ease of preparation, and the nutritional value of fish $[52,53]$.

Table 3. The fish, animal, and total protein intake across Eastern African countries in 2013, compared to Africa and the global status.

\begin{tabular}{|c|c|c|c|c|c|c|c|}
\hline $\begin{array}{l}\text { Region/ } \\
\text { Countries }\end{array}$ & $\begin{array}{l}\text { Population } \\
\text { (Thousands) }\end{array}$ & $\begin{array}{c}\text { Total Food } \\
\text { Fish Supply } \\
\text { (Tonnes) }\end{array}$ & $\begin{array}{c}\text { Fish } \\
\text { Consumption } \\
\text { (kg/Person/Year) }\end{array}$ & $\begin{array}{l}\text { Fish Protein } \\
\text { (g/Person/Day) }\end{array}$ & $\begin{array}{c}\text { Animal } \\
\text { Protein } \\
\text { (g/Person/Day) }\end{array}$ & $\begin{array}{l}\text { Fish/Animal } \\
\text { Protein (\%) }\end{array}$ & $\begin{array}{c}\text { Fish/Total } \\
\text { Protein (\%) }\end{array}$ \\
\hline World & $7,162,118$ & $142,126,714$ & 19.8 & 5.4 & 32.1 & 16.9 & 6.7 \\
\hline Africa & $1,110,636$ & $11,225,497$ & 10.1 & 2.9 & 16.0 & 18.4 & 4.4 \\
\hline Burundi & 10,163 & 20,145 & 2.0 & 0.6 & 2.2 & 28.1 & 1.7 \\
\hline Ethiopia & 94,101 & 39,347 & 0.4 & 0.1 & 7.7 & 1.6 & 0.2 \\
\hline Kenya & 44,354 & 181,227 & 4.1 & 1.2 & 15.8 & 7.3 & 1.9 \\
\hline Rwanda & 11,777 & 52,910 & 4.5 & 1.5 & 5.8 & 25.1 & 2.5 \\
\hline Tanzania & 49,253 & 352,304 & 7.2 & 2.3 & 10.4 & 22.5 & 4.0 \\
\hline Uganda & 37,579 & 469,773 & 12.5 & 3.7 & 12.4 & 30.1 & 7.1 \\
\hline
\end{tabular}

Data Source: UN-DESA [21] and WAPI- FISHCSP v.2018.1 [27]

Fish is often considered to be a 'rich food for poor people' [8]. Fish is the most accessible and affordable source of animal protein, providing many of the key nutrients and calories that are needed for physical and mental development [54]. For example, analysis by [55] on the consumption patterns of different types of proteins in Kenya show that wild-caught, followed by pond fish, make up a large proportion of the total protein that is consumed by respondents from 'poor' socioeconomic classes (Figure 1). The results further indicate that as households become wealthier, "terrestrial 
sources of animal protein" (e.g., chicken, beef, mutton and pork) occupy increasingly larger shares of total protein consumption. Conversely, as socioeconomic status declines, fish becomes increasingly important. This implies that the poorer the households, the more important fish is to their total protein intake. Therefore, [55] concluded that although formidable fish supply chain issues remain, many families-including poor families—had attained meaningful food security benefits from aquaculture. As a result, more action is needed to address the economic constraints that are plaguing the sector.

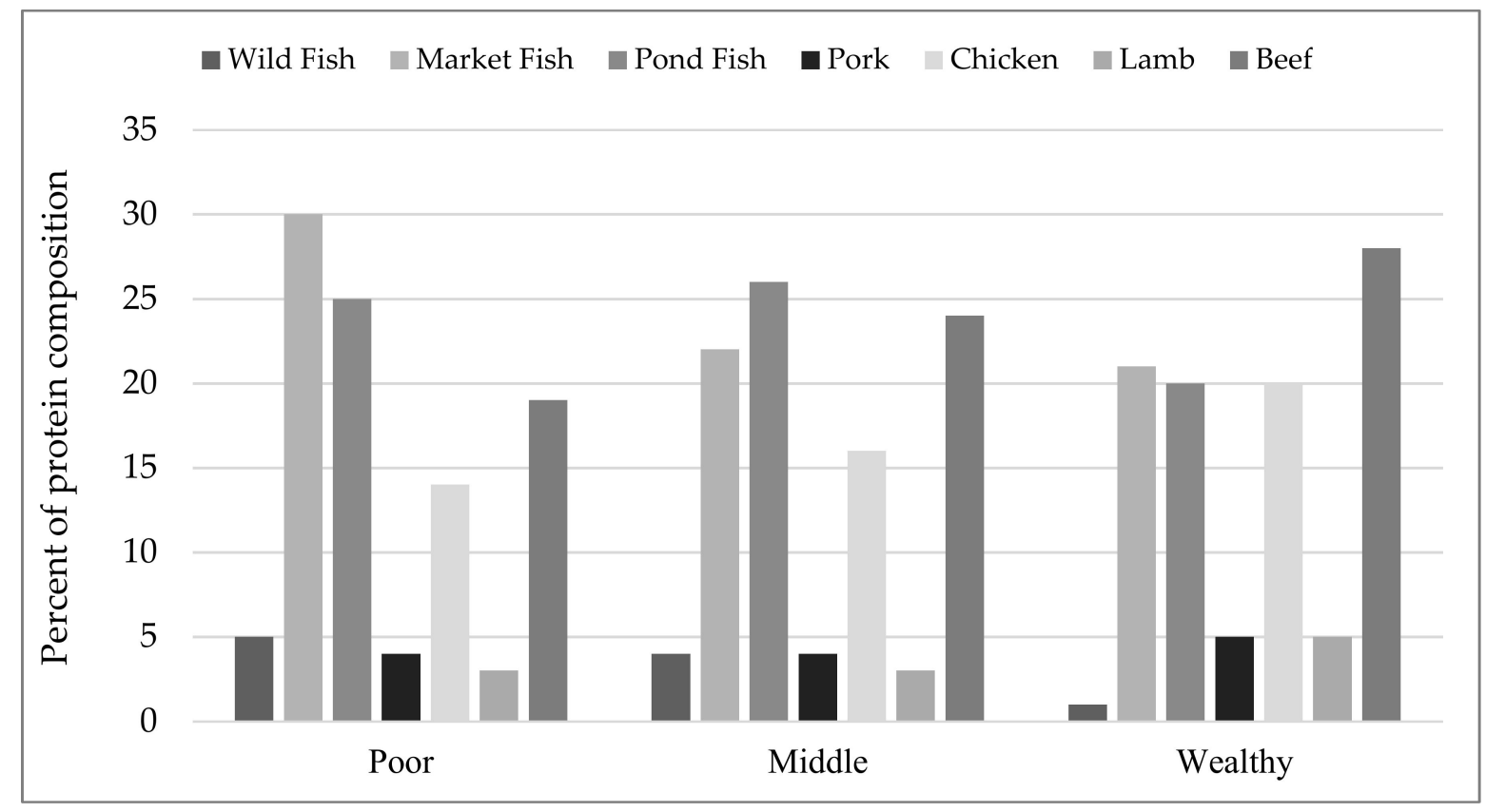

Figure 1. Protein consumption composition by socioeconomic classes according to the Kenya Bureau of Statistics (KNBS). Data modified from [55].

\subsection{Fish Trade and Marketing}

Fish and fishery products remain the most well traded food items worldwide [7,14]. International trade is crucial to the fisheries sector, especially in the least advanced economies, through the creation of employment, supplying food, generating income, and thus contributing to maintaining food and nutrition security $[14,56]$. According to [7], about $35 \%$ of the world's fish production is traded internationally for human consumption and non-edible purposes. Over the past 40 years, the trade in fish and fish products increased significantly in value terms, from US\$8 billion in 1976, to US\$143 billion in 2016 [7]. Approximately half of the fish consumed by developed country markets, like the United States (US) and the European Union (EU) originates from developing countries [12].

Despite the relatively high contribution of developing countries to global trade, millions of people in developing countries consume fish protein in their diets, compared to those living in developed countries [12]. Furthermore, [57] demonstrated that domestic consumption accounts for approximately $90 \%$ of the total fish production in developing countries. Recent evidence further reveals that cultured fish in the Global South markets is increasingly available to poor rural and urban consumers, thus creating 'new geographies of consumption' [57]. These changing consumption patterns dispel widely held narratives that farmed fish is, "mostly exported to the wealthy countries of Europe and North America or consumed by the growing middle-classes in the megacities of these economies" [6]. This trend is likely to result in the diversification of product and market strategies towards smaller, cheaper and relatively more accessible fish [58,59].

The traditional focus on large export-oriented international trading blocs like the EU and US markets has meant that less attention has been paid to developing regional trade, which is thought to have great potential [60]. Empirical evidence by the United Nations Conference on Trade and 
Development (UNCTAD) reveal three emerging challenges that hinder global fish trade [56]. First, fish products are relatively more affected by Non-Tariff Measures (NTMs), compared to non-fish products. Second, fish products are mostly affected by technical regulations related to sanitary and phytosanitary standards (SPS) and technical barriers to trade (TBTs) [56]. Third, most countries impose SPS regulations on imported fish products [56]. In the East African Community (EAC) and the Common Market for Eastern and Southern Africa and East African Community (COMESA) regions, the most pressing issues facing regional fisheries trade relate to non-tariff barriers such as export licensing, logistics and poor infrastructure, lack of quality assurance, and high post-harvest losses, which significantly hinder domestic and intra-regional trade [60]. Compounding these challenges is an inadequate level of knowledge or empirical evidence to inform policy development and implementation, as well as practical conduct of cross-border trade [61].

Fish trade in East Africa has become bidirectional. On one hand, fish exports exceed imports in value terms in the region, as a result of the export of premium products to higher income countries particularly in the European Union, Far East and Middle East Countries, and the United States of America [60,61]. Three East African countries (Uganda, Tanzania and Kenya) have lucrative export markets for Nile perch from capture fisheries, in addition to high-value seafood, mainly composed of frozen tuna, octopus, fillets, snappers, prawns, and lobsters caught in the Indian Ocean from Kenya and Tanzania. On the other hand, East Africa is also an importer of frozen tilapia, mackerels, sardines, prawns and salmons. Tilapia imported from China has dominated whole fish and frozen fillet forms on the East African market. Over the past five years, the value of fish exports has slightly declined, while the import value increased by $44 \%$, driven by population increases versus declining supplies from capture fishers, a growing awareness of fish as being a healthy food in diets, and urbanization (Figure 2). Aquaculture products, especially of fresh frozen Nile tilapia, are mostly consumed locally.

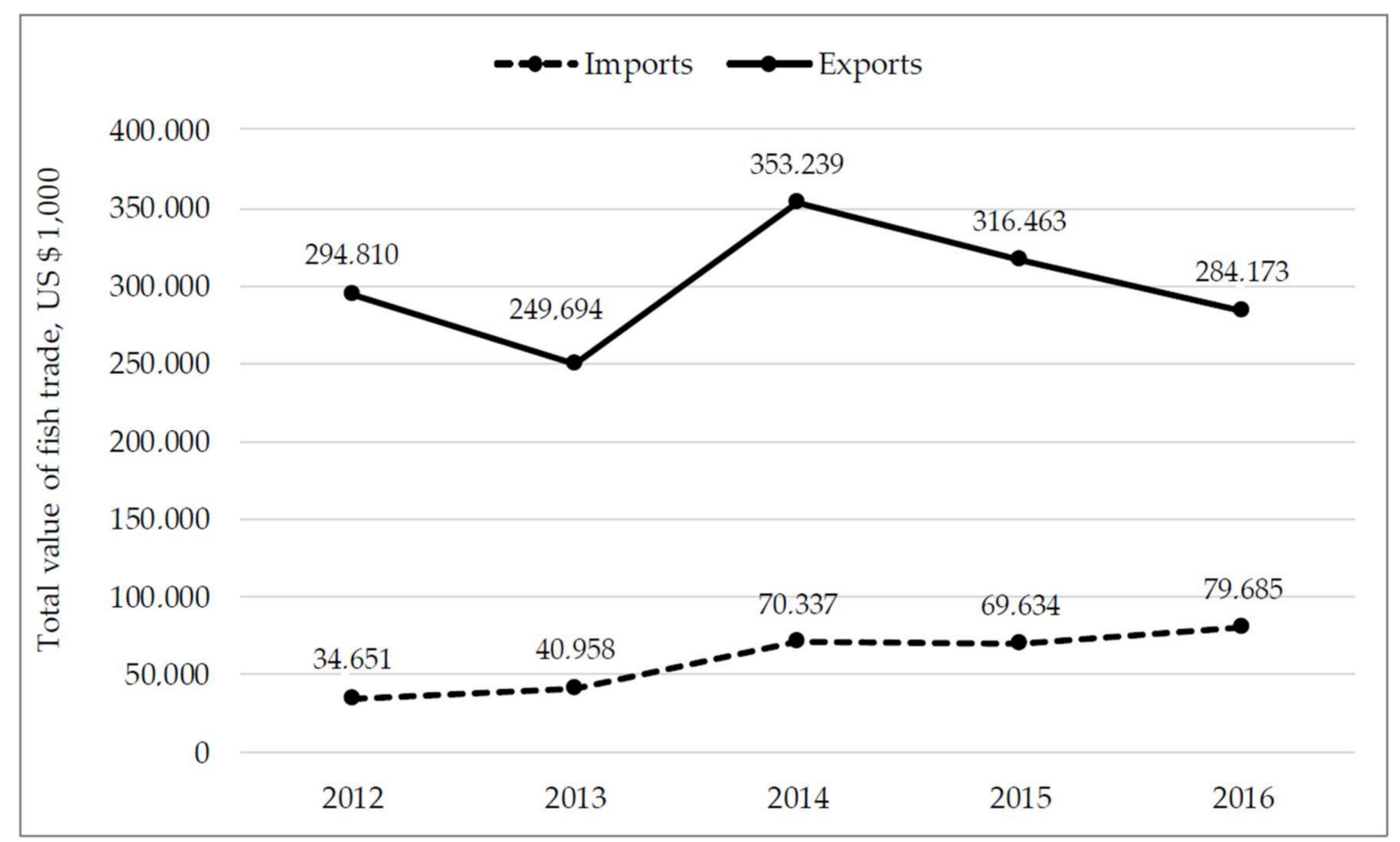

Figure 2. Total value of international imports and exports of fish and fishery commodities in East Africa (2012-2016). Data source [62].

Fish trade in the EA subregion has increased the scope and choice of fish that are available to consumers, because of improved logistics and market distribution systems, coupled with expanding aquaculture production and technological innovations. Furthermore, as the distance becomes less of a barrier to trade, wholesalers and retailers source fish from all over the world, especially from China, to 
bridge the growing demand for fish in the region, against the fluctuating supply from capture fisheries and aquaculture. Consequently, fish traders rely on imported frozen fish, due to its ease of availability, steady supply, and price. This results in a dependency on the supply of imported frozen tilapia fish, which are sold in major cities and distant markets at a lower price. Price trends for imported frozen and filleted fish over the past year reveal a slight price increase for all grades of $10 \mathrm{~kg}$ boxed whole tilapia in Nairobi (Table 4). This translates to an average price of $1 \mathrm{~kg}$ of fish, at US\$2.5 per $\mathrm{kg}$. In this scenario, most of the actors in the aquaculture value chain, including producers and suppliers, do not benefit, due to out-competition, since fish producers need to sell at an average price of US\$4.5 and above to break even on production costs.

Table 4. Imported frozen whole tilapia prices in Nairobi, showing changes in prices (Kenya Shillings-KES) from May 2017 to September 2018. Source: KMFRI Field Survey Data 2017 and 2018.

\begin{tabular}{ccc}
\hline Grade Per 10 kg Box & $\begin{array}{c}\text { Price in KES of Imported Frozen } \\
\text { Tilapia in November 2017 }\end{array}$ & $\begin{array}{c}\text { Price in KES of Imported Frozen } \\
\text { Tilapia in September 2018 }\end{array}$ \\
\hline $100 / 200$ & 1250 & 1350 \\
$200 / 300$ & 1500 & 1550 \\
$300 / 400$ & 1650 & 1850 \\
$400 / 600$ & 1900 & 2150 \\
$600 / 800$ & 2000 & 2350 \\
$800 / 1000$ & 2200 & 2400 \\
$1000 /$ UP & 2250 & 2500 \\
\hline
\end{tabular}

\subsection{Projections of Fish Demand and Supply Gaps}

Fish consumption is anticipated to increase in all continents, except in Africa. The report reveals that the current level of fish consumption of $9.9 \mathrm{~kg}$ during 2015-2017 in Africa may decline to $9.6 \mathrm{~kg}$ by 2027 [14]. Despite the projected decline in fish consumption in Africa, there is a growing demand and supply gap corresponding to a steady population growth. As such, Africa is projected to become increasingly reliant on fish importation, growing at $2.5 \%$ p.a. to contribute $43 \%$ of the total fish consumed in Sub-Saharan Africa by 2017 [14,30]. Results from the IMPACT Model projections reveal three emerging trends in Africa's fish demand and supply: (1) much lower fish consumption levels; (2) widening fish food deficits; and (3) low contributions of farmed fish to the total fish output [25]. Under the business-as-usual scenario, capture fisheries and aquaculture will experience sluggish growth, while fish consumption per capita will slightly decline from $10.1 \mathrm{~kg}$ in 2013 to $8.5 \mathrm{~kg}$ in 2030, and ultimately to $7.7 \mathrm{~kg}$ by 2050 [25].

Furthermore, a recent FAO study projects slight growth in fish consumption per capita, despite high population growth projections in the Eastern Africa region [28]. Between 2008-2013, the region realized the least per capita fish consumption in African. Nonetheless, there was increased fish consumption, by $2.6 \%$ from $4.22 \mathrm{~kg}$ to $4.79 \mathrm{~kg}$ (Table 5) [28]. Notwithstanding national variations, given the fixed fish prices and preferences, coupled with rising income levels, the region is projected to experience slight increases in fish consumption from $4.8 \mathrm{~kg}$ in 2013 to $5.49 \mathrm{~kg}$ in 2022 [28]. Because of the rising population growth and increasing income levels, the East African regions will need 2.49 million tonnes of fish to fill the demand-supply gaps. The demand generated by income and population growth is estimated at 584,130 tonnes annually. While regional aquaculture production was projected to grow by $6.6 \%$ p.a. from the mid-2010s to the early 2020 s, it will require $30.38 \%$ (or $25.37 \%$ under conservative projections) annual growth to close the regional demand-supply gap in the next five years. Meanwhile, Ethiopia, Burundi and Tanzania would need to realize over $80 \%$ annual growth in aquaculture production to fill the demand deficit. 
Table 5. Summary of demand-supply gap projections from the mid-2010s to the early 2020s in Eastern African Countries.

\begin{tabular}{|c|c|c|c|c|c|c|c|c|c|c|}
\hline \multirow[b]{2}{*}{$\begin{array}{l}\text { Country or } \\
\text { Country } \\
\text { Group }\end{array}$} & \multicolumn{3}{|c|}{ Baseline Scenario in the Mid-2010s } & \multicolumn{3}{|c|}{ Fish Production Projection in the Early 2020s } & \multicolumn{4}{|c|}{ Demand and Supply Growth from the Mid-2010s to the Early 2020s } \\
\hline & $\begin{array}{l}\text { Aquaculture } \\
\text { Production } \\
\text { (Tonnes) }\end{array}$ & $\begin{array}{l}\text { Per Capita } \\
\text { Consumption } \\
\quad(\mathrm{kg})\end{array}$ & $\begin{array}{c}\text { Total } \\
\text { Consumption } \\
\text { (Tonnes) }\end{array}$ & $\begin{array}{l}\text { Aquaculture } \\
\text { Production } \\
\text { (Tonnes) }\end{array}$ & $\begin{array}{l}\text { Per Capita } \\
\text { Demand (kg) }\end{array}$ & $\begin{array}{c}\text { Total } \\
\text { Demand } \\
\text { (Tonnes) }\end{array}$ & $\begin{array}{l}\text { Extra Food } \\
\text { Fish Supply } \\
\text { (Tonnes) }\end{array}$ & $\begin{array}{l}\text { Annual } \\
\text { Growth } \\
\text { Rate (\%) }\end{array}$ & $\begin{array}{l}\text { Demand } \\
\text { Generated by } \\
\text { Income and } \\
\text { Population } \\
\text { Growth (Tonnes) }\end{array}$ & $\begin{array}{c}\text { Annual } \\
\text { Aquaculture } \\
\text { Growth Rate } \\
\text { Needed to Close } \\
\text { the Demand } \\
\text { Supply Gap (\%) }\end{array}$ \\
\hline SSA & 662,340 & 8.66 & $8,707,270$ & 915,060 & 9.78 & $11,184,820$ & 272,720 & 7.33 & $2,477,550$ & 37.17 \\
\hline East Africa & 211,060 & 4.80 & $1,901,110$ & 290,520 & 5.49 & $2,485,240$ & 79,460 & 6.60 & 584,130 & 30.38 \\
\hline Burundi & 230 & 1.92 & 21,880 & 390 & 2.07 & 27,590 & 160 & 11.08 & 5720 & 91.51 \\
\hline Ethiopia & 80 & 0.24 & 24,560 & 140 & 0.28 & 32,120 & 50 & 10.44 & 7560 & 146.68 \\
\hline Kenya & 32,830 & 4.34 & 202,570 & 51,320 & 4.95 & 261,470 & 18,490 & 9.34 & 58,900 & 22.81 \\
\hline Rwanda & 1880 & 4.12 & 48,450 & 3460 & 4.79 & 62,900 & 1580 & 12.99 & 14,450 & 54.14 \\
\hline Tanzania & 5280 & 5.48 & 297,650 & 9420 & 6.23 & 393,540 & 4140 & 12.27 & 95,890 & 80.49 \\
\hline Uganda & 115,580 & 12.84 & 509,530 & 142,900 & 14.25 & 664,030 & 27,320 & 4.33 & 154,500 & 18.50 \\
\hline
\end{tabular}




\section{Conclusions and Recommendations}

This paper synthesizes and provides information on the important role of fish in food security, based on production and consumption trends, trade, marketing, and future demand and supply gaps in the Eastern African region. At regional levels, fish production and supply are dominated by capture fisheries, while aquaculture production is modest compared to the top producers in Africa. Fish consumption is characterized by an increasing supply deficit, and low per capita fish protein intake. Correspondingly, the proportion of fish in animal protein intake in most countries in the region is less than the world average, signifying the crucial role that fish plays in food security and nutrition. Fish trade in the region is characterized with a steady increase in fish imports, due to fluctuating supplies from natural systems and steady population growth, as well as improved logistics reducing distance barriers and market distribution systems.

Given fixed fish prices and preferences coupled with rising income levels, the East African region is projected to realize increased fish consumption from $4.80 \mathrm{~kg}$ in 2013 to $5.49 \mathrm{~kg}$ in 2022 . As a result of the rising population growth and increasing income levels, the East African regions will need 2.49 million tonnes of fish to fill the demand-supply gap. This widening demand and supply gap presents a host of new development opportunities for the smallholder farmers to invest in efficient production systems to significantly contribute to fish consumption, reducing rural poverty and unemployment. Attention should also be given to reduce post-harvest losses, which are currently estimated at over $20 \%$, especially for the freshwater silver cyprinids, which contribute significantly to protein consumption in the region. This would involve an improvement in value chain efficiency, better infrastructure, preservation facilities and value-addition technologies, and in market information and linkages.

Based on the findings of this research, we propose further research into three main areas. First, continuous assessment and compilation of current research is needed, to fill gaps in understanding the nutritional values of the main species of fish consumed in urban and rural areas. Second, more robust projection models are needed, to better understand fish demand and supply projections beyond 2030, since the region's population is expected to double by 2050. Third, further research is required to investigate the nutritional benefits of fish consumption, and drivers of consumer taste and preferences, especially in areas where fish has not been traditionally consumed. Future studies should also focus on the types of fish that are consumed and the nutritional effects of different fish-processing methods, as well as the socioeconomic and cultural issues influencing fish consumption options.

Looking into the future, the potential for aquaculture as a new frontier for development looks bright. More public and private investments are needed to maximize aquaculture's full potential, to improve the region's food and nutrition status. Now and in the future, fish consumption may increase with increased aquaculture production and importation of fish products, provided the barriers to intra-regional trade are addressed through ratifying regional and international trade agreements. Food security and nutritional programmes should recognize the potential of fish in providing essential micronutrients for improved dietary quality, nutritional status, and the general wellbeing of the region's fast-growing population.

Author Contributions: Study conceptualization, K.O., H.W., B.K., and P.A.; Literature review K.O., S.D., P.M., and A.D.; Writing-original draft preparation, K.O., S.D., and P.M.; Writing-review and editing, K.O., H.W., S.D., P.M., P.A., R.O., A.D.; Supervision, H.W., B.K., and P.A.

Funding: We acknowledge financial support from the Austrian Agency for International Cooperation in Education and Research (OeAD-GmbH) under the Austrian Partnership Programme in Higher Education and Research for Development (APPEAR) [Grant Number 101, 2015-2018].

Acknowledgments: Special thanks to the project coordinators for the APPEAR funded project "Strengthening Regional Capacity in Research and Training in Fisheries and Aquaculture for Improved Food Security and Livelihoods in Eastern Africa" (STRECAFISH) for guidance and logistical support. We are indebted Richard Abila and anonymous reviewers for comments on an earlier draft of the paper.

Conflicts of Interest: The authors declare that they have no conflict of interest. 


\section{References}

1. United Nations. Transforming Our World: The 2030 Agenda for Sustainable Development, A/RES/70/1. 2015. Available online: https://www.refworld.org/docid/57b6e3e44.html (accessed on 24 November 2018).

2. FAO; IFAD; UNICEF; WFP WHO. The State of Food Security and Nutrition in the World 2018. Building Climate Resilience for Food Security and Nutrition; FAO: Rome, Italy, 2018; Available online: http:/ / www.fao.org/3/ I9553EN/i9553en.pdf (accessed on 20 October 2018).

3. Searchinger, T.; Waite, R.; Hanson, C.; Ranganathan, J.; Dumas, P. Creating a Sustainable Food Future: A Menu of Solutions to Feed Nearly 10 Billion People by 2050; World Resaurce Institute: Washington, DC, USA, 2018; Available online: https://www.wri.org/our-work/project/world-resources-report/publications (accessed on 7 January 2019).

4. Nelson, G.; Bogard, J.; Lividini, K.; Arsenault, J.; Riley, M.; Sulser, T.B.; Mason-D'Croz, D.; Power, B.; Gustafson, D.; Herrero, M.; et al. Income growth and climate change effects on global nutrition security to mid-century. Nat. Sustain. 2018, 1,773-781. [CrossRef]

5. Swinburn, B.A.; Kraak, V.I.; Allender, S.; Atkins, V.J.; Baker, P.I.; Bogard, J.R.; Brinsden, H.; Calvillo, A.; De Schutter, O.; Devarajan, R.; et al. The global syndemic of obesity, undernutrition, and climate change: The Lancet commission report. Lancet 2019, 393, 791-846. [CrossRef]

6. Golden, C.D.; Allison, E.H.; Cheung, W.W.L.; Dey, M.M.; Halpern, B.S.; McCauley, D.J.; Smith, M.; Vaitla, B.; Zeller, D.; Myers, S.S. Nutrition: Fall in fish catch threatens human health. Nature 2016, 534, 317-320. [CrossRef]

7. Food and Agriculture Organization of the United Nations (FAO). The State of World Fisheries and Aquaculture 2018-Meeting the Sustainable Development Goals; FAO: Rome, Italy, 2018.

8. Beveridge, M.C.M.; Thilsted, S.H.; Phillips, M.J.; Metian, M.; Troell, M.; Hall, S.J. Meeting the food and nutrition needs of the poor: The role of fish and the opportunities and challenges emerging from the rise of aquaculture. J. Fish Biol. 2013, 83, 1067-1084. [CrossRef]

9. Food and Agriculture Organization of the United Nations (FAO). FAO Working for SDG 14: The Special Role of Fish in Human Nutrition; FAO: Rome, Italy, 2017; Available online: http:/ / www.fao.org/3/a-i7298e.pdf (accessed on 2 November 2018).

10. Anderson, J.L.; Asche, F.; Garlock, T.; Chu, J. Aquaculture: Its role in the future of food. In Frontiers of Economics and Globalization; Emerald Publishing Limited: Bradford, UK, 2017; Volume 17, pp. 159-173.

11. Cai, J.; Huang, H.; Leung, P.S. Understanding the Contribution of Aquaculture and Fisheries to GDP; FAO Fisheries and Aquaculture Technical Paper No. 606; FAO: Rome, Italy, 2019; 80p.

12. Bush, S.R.; Oosterveer, P. Governing Sustainable Seafood; Taylor \& Francis Group: New York, NY, USA, 2019.

13. Food and Agriculture Organization of the United Nations (FAO). The State of World Fisheries and Aquaculture 2016. Contributing to Food Security and Nutrition for All; FAO: Rome, Italy, 2016.

14. Organisation for Economic Co-operation and Development (OECD); Food and Agriculture Organization of the United Nations (FAO). Chapter 8. Fish and seafood. In OECD/FAO Agricultural Outlook 2018-2027; FAO: Rome, Italy, 2018; pp. 175-190. Available online: http:/ /www.fao.org/docrep/i9166e/i9166e_Chapter8_ Fish_seafood.pdf (accessed on 5 February 2019).

15. De Graaf, G.J.; Garibaldi, L. The Value of African Fisheries; Vol FIPS/C1093, FAO: Rome, Italy, 2014; 67p, Available online: http:/ / www.fao.org/documents/card/es/c/d155e4db-78eb-4228-8c8c-7aae5fc5cb8e/ (accessed on 29 January 2019).

16. AUC-NEPAD. The Policy Framework and Reform Strategy for Fisheries and Aquaculture in Africa; NEPAD: Johannesburg, South Africa, 2014; Available online: http:/ / www.au-ibar.org/general-publications\%5Cnhttp: / / rea.au.int/en/content/policy-framework-and-reform-strategy-fisheries-and-aquaculture-africa (accessed on 15 January 2019).

17. Food and Agriculture Organization of the United Nations (FAO). Regional Overview of Food Security and Nutrition in Africa 2017. The Food Security and Nutrition-conflict Nexus: Building Resilience for Food Security, Nutrition and Peace; FAO: Accra, Ghana, 2017.

18. Hecht, T. Regional Review on Aquaculture Development 4. Sub-Saharan Africa-2005; FAO: Rome, Italy, 2006; Available online: http://www.fao.org/docrep/pdf/009/a0619e/a0619e00.pdf (accessed on 12 December 2018). 
19. Food and Agriculture Organization of the United Nations (FAO). Regional Review on Status an Trends in Aquaculture Development in Sub-Saharan Africa-2015; Satia, B., Ed.; Fisheries and Aquaculture Circular No. 1135/2; FAO: Rome, Italy, 2017; Volume 4.

20. Hounmanou, Y.M.G.; Mdegela, R.H.; Dougnon, T.V.; Achoh, M.E.; Mhongole, O.J. Tilapia lake virus threatens tilapiines farming and food security: Socio-economic challenges and preventive measures in Sub-Saharan Africa. Aquaculture 2018, 493, 23-129. [CrossRef]

21. United Nations Department of Economic and Social Affairs (UN-DESA). World Population Prospects: The 2017 Revision, Key Findings and Advance Tables; UN-DESA: New York, NY, USA, 2017; Available online: https:/ / esa.un.org/unpd/wpp/publications/files/wpp2017_keyfindings.pdf (accessed on 12 January 2019).

22. Kobayashi, M.; Msangi, S.; Batka, M.; Vannuccini, S.; Dey, M.M.; Anderson, J.L. Fish to 2030: The role and opportunity for aquaculture. Aquacult. Econ. Manag. 2015, 19, 282-300. [CrossRef]

23. Golden, C.D.; Seto, K.L.; Dey, M.M.; Chen, O.L. Does aquaculture support the needs of nutritionally vulnerable nations? Front. Mar. Sci. 2017. [CrossRef]

24. SOFI. World Hunger and Poverty Facts and Statistics. 2015. Available online: http:/ /www.worldhunger. org/2015-world-hunger-and-poverty-facts-and-statistics / (accessed on 12 January 2019).

25. Chan, C.Y.; Tran, N.; Pethiyagoda, S.; Crissman, C.C.; Sulser, T.B.; Phillips, M.J. Prospects and challenges of fish for food security in Africa. Glob. Food Secur. 2019, 20, 17-25. [CrossRef]

26. Food and Agriculture Organization of the United Nations (FAO). World Aquaculture Performance Indicators (WAPI)—Aquaculture Production Module (WAPI-AQPRN v.2018.1); FAO: Rome, Italy, 2018; Available online: www.fao.org/fishery/statistics/software/wapi/enpdf (accessed on 25 November 2018).

27. Food and Agriculture Organization of the United Nations (FAO). World Aquaculture Performance Indicators (WAPI)_Fish Consumption Module (WAPI-FISHCSP v.2018.1); FAO: Rome, Italy, 2018; Available online: www.fao.org/fishery/statstics/software/wapi/enpdf (accessed on 26 November 2018).

28. Cai, J.; Leung, P.S. Short-Term Projection of Global Fish Demand and Supply Gaps; FAO Fisheries and Aquaculture Technical Paper No. 607; FAO: Rome, Italy, 2017.

29. Chan, C.Y.; Tran, N.; Dao, D.C.; Sulser, T.B.; Phillips, M.J.; Batka, M.; Wiebe, K.; Preston, N. Fish to 2050 in the ASEAN Region; WorldFish: Penang, Malaysia; International Food Policy Research Institute (IFPRI): Washington, DC, USA, 2017.

30. Tran, N.; Chu, L.; Chan, C.Y.; Genschick, S.; Phillips, M.; Kefi, A.S. Fish supply and demand for food and nutrition security in Sub-Saharan Africa: An analysis of the Zambian fish sector. Mar. Policy 2019, 99, 343-350. [CrossRef]

31. Mwima, H.; Monor, V.G.; Mbilinyi, H.G.; Rathacharen, S.; Omanyi, P.B.; Katonda, I.K. Regional Assessment of Fisheries Issues, Challenges and Opportunities for Eastern Africa Region; AU-IBAR: Nairobi, Kenya, 2012; Available online: http://www.au-ibar.org/general-publications.

32. Obiero, K.O.; Abila, R.O.; Njiru, M.J.; Raburu, P.O.; Achieng, A.O.; Kundu, R.; Ogello, E.O.; Munguti, J.M.; Lawrence, $\mathrm{T}$. The challenges of management: Recent experiences in implementing fisheries co-management in Lake Victoria, Kenya. Lakes Reserv. Manag. 2015, 3, 139-154. [CrossRef]

33. Sayer, C.A.; Máiz-Tomé, L.; Darwall, W.R.T. (Eds.) Freshwater Biodiversity in the Lake Victoria Basin: Guidance for Species Conservation, Site Protection, Climate Resilience and Sustainable Livelihoods; IUCN: Cambridge, UK; Gland, Switzerland, 2018.

34. Hecky, R.E.; Mugidde, R.; Ramlal, P.S.; Talbot, M.R.; Kling, G.W. Multiple stressors cause rapid ecosystem change in Lake Victoria. Freshwater Biol. 2010, 55, 19-42. [CrossRef]

35. De San, M. Report of Five EAC's Countries Aquaculture Situation, Needs and Regional Expectations; Report/Rapport: FAO SmartFish Publication No. SF-FAO/2013/12; FAO: Arusha, Tanzania, 2013.

36. Rothuis, A.; Turenhout, M.; van Duijn, A. Aquaculture in East Africa; A Regional ApproachRoem, A., Rurangwa, E., Katunzi, E., Shoko, A., Kabagambe, J.B., Eds.; A Regional ApproachLEI Report IMARES C153/14 I LEI 14-120 (University \& Research centre); Wageningen University: Wageningen, The Netherlands, 2014; 54p.

37. Hyua, T.; Ekere, W.; Egna, H.; Molnar, J. Social and economic performance of Tilapia farming in Uganda. In Social and Economic Performance of Tilapia Farming in Africa; Cai, J., Quagrainie, K., Hishamunda, N., Eds.; Fisheries and Aquaculture Circular No. 1130; FAO: Rome, Italy, 2017; pp. 127-144.

38. Kenya National Bureau of Statistics (KNBS). Economic Survey 2018; Kenya National Bureau of Statistics (KNBS): Nairobi, Kenya, 2018. 
39. United Nations. World Economic Situation and Prospects 2019; United Nations: New York, NY, USA, 2019; Available online: https:/ / www.un.org/development/desa/dpad/wp-content/uploads/sites/45/ WESP2019_BOOK-web.pdf (accessed on 4 February 2019).

40. African Union Commission New Partnership For Africa's Development (AUC-NEPAD). Malabo Declaration on Accelerated Agricultural Growth and Transformation for Shared Prosperity and Improved Livelihoods. 2003. Available online: https://www.nepad.org/caadp/publication/malabo-declaration-acceleratedagricultural-growth (accessed on 6 February 2019).

41. Food and Agriculture Organization of the United Nations (FAO). World Food and Agriculture-Statistical Pocketbook 2018; Rome: Licence: CC BY-NC-SA 3.0 IGO; FAO: Rome, Italy, 2018; Available online: https://www.un.org/development/desa/dpad/wp-content/uploads/sites/45/WESP2019_BOOKweb.pdf (accessed on 5 February 2019).

42. World Health Organization (WHO). Nutrition Landscape Information Systems (NLIS): Country Profile Indicators-Interpretation Guide; WHO: Geneva, Switzerland, 2010; Interpretation.

43. Kris-Etherton, P.M.; Harris, W.S.; Appel, L.J. Fish consumption, fish oil, omega-3 fatty acids, and cardiovascular disease. J. Am. Heart Assoc. 2002, 2747-2757. [CrossRef]

44. Willett, W.; Rockström, J.; Loken, B.; Springmann, M.; Lang, T.; Vermeulen, S.; Garnett, T.; Tilman, D.; DeClerck, F.; Wood, A.; et al. Food in the anthropocene: The EAT-Lancet commission on healthy diets from sustainable food systems. Lancet 2019, 393, 447-492. [CrossRef]

45. Thilsted, S.H.; Thorne-Lyman, A.; Webb, P.; Bogard, J.R.; Subasinghe, R.; Phillips, M.J.; Allison, E.H. Sustaining healthy diets: The role of capture fisheries and aquaculture for improving nutrition in the post-2015 era. Food Policy 2016, 61, 126-131. [CrossRef]

46. Bennett, A.; Patil, P.; Kleisner, K.; Doug, R.; Virdin, J.; Basurto, X. Contribution of Fisheries to Food Security: Current Knowledge, Policy and Research; NI Report 18-02; Duke University: Durham, NC, USA, 2018; Available online: http:/ / nicholasinstitute.duke.edu/publication.

47. Longley, C.; Thilsted, S.H.; Beveridge, M.; Cole, S.; Nyirenda, D.B.; Heck, S.; Hother, A.-L. The role of fish in the first 1000 Days in Zambia; IDS Special Collection; Institute of Development Studies: Brighton, UK, 2014; pp. 17-35.

48. Hammerl, K. The Potential of Fish Farming to Contribute to the Reduction of Undernutrition in Children. Ph.D. Thesis, University of Vienna, Vienna, Austria, 2013.

49. Aiga, H.; Matsuoka, S.; Kuroiwa, C.; Yamamoto, S. Malnutrition among children in rural Malawian fish-farming households. Trans. R. Soc. Trop. Med. Hyg. 2009, 103, 827-833. [CrossRef]

50. Béné, C.; Arthur, R.; Norbury, H.; Allison, E.H.; Beveridge, M.; Bush, S.; Campling, L.; Leschen, L.; Little, D.; Squares, D.; et al. Contribution of fisheries and aquaculture to food security and poverty reduction: Assessing the current evidence. World Dev. 2016, 79, 177-196. [CrossRef]

51. Little, D.C.; Newton, R.W.; Beveridge, M. Aquaculture: A rapidly growing and significant source of sustainable food? Status, transitions and potential. Proc. Nutr. Soc. 2016, 75, 274-286. [CrossRef]

52. Darko, F.A.; Quagrainie, K.K.; Chenyambuga, S. Consumer preferences for farmed tilapia in Tanzania: A choice experiment analysis. J. Appl. Aquacult. 2016, 3, 131-143. [CrossRef]

53. Githukia, C.M.; Obiero, K.O.; Manyala, J.O.; Ngugi, C.C.; Quagrainie, K.K. Consumer perceptions and preferences of wild and farmed Nile Tilapia (Oreochromis niloticus L.) and African Catfish (Clarias gariepinus Burchell 1822) in urban centres in Kenya. Int. J. Adv. Res. 2014, 7, 694-705.

54. Béné, C.; Barange, M.; Subasinghe, R.; Andersen, P.P.-A.; Merino, G.; Hemre, G.; Williams, M. Feeding 9 billion by 2050-Putting fish back on the menu. Food Secur. 2015, 2, 261-274. [CrossRef]

55. Ole-MoiYoi, L.K. Fishing for Answers: Can Aquaculture Transform Food Security in Rural Kenya? Ph.D. Thesis, Stanford University, Stanford, CA, USA, 2017. Available online: http://purl.stanford.edu/ zf051hh9063 (accessed on 7 January 2019).

56. Fugazza, M. Fish Trade and Policy: A Primer on Non-Tariff Measures. 2017. Available online: https:/ / unctad.org/en/PublicationsLibrary/ser-rp-2017d7_en.pdf (accessed on 11 January 2019).

57. Belton, B.; Bush, S.R.; Little, D.C. Not just for the wealthy: Rethinking farmed fish consumption in the Global South. Global Food Secur. 2018, 16, 85-92. [CrossRef]

58. Genschick, S.; Marinda, P.; Tembo, G.; Kaminski, A.M.; Thilsted, S.H. Fish consumption in urban Lusaka: The need for aquaculture to improve targeting of the poor. Aquaculture 2018, 492, 280-289. [CrossRef] 
59. Kaminski, A.M.; Genschick, S.; Kefi, A.S.; Kruijssen, F. Commercialization and upgrading in the aquaculture value chain in Zambia. Aquaculture 2018, 493, 355-364. [CrossRef]

60. Ward, A. Training for Fish Quality Improvement: Training Needs Analysis; FAO: Rome, Italy, 2011.

61. African Union Interafrican Bureau for Animal Resources (AU-IBAR). Fish. Trade and Marketing for Food Security and Livelihoods in Africa; Report/Rapport" SF/2011/10.2018; Indian Ocean Commission: Nairobi, Kenya, 2018.

62. Food and Agriculture Organization of the United Nations (FAO). FAO Yearbook. Fishery and Aquaculture Statistics-2015; FAO: Rome, Italy, 2017.

(C) 2019 by the authors. Licensee MDPI, Basel, Switzerland. This article is an open access article distributed under the terms and conditions of the Creative Commons Attribution (CC BY) license (http://creativecommons.org/licenses/by/4.0/). 